\title{
PEMENUHAN KEBUTUHAN DASAR PADA LANSIA MENINGKATKAN KUALITAS HIDUP DI JAKARTA SELATAN
}

\author{
Yusriana $^{1 *}$, Etty Rekawati ${ }^{2}$, Dwi Nurviyandari ${ }^{2}$
}

1. Yusriana : STIKes MERCUBAKTIJAYA Padang Jln Jamal Jamil Pondok KopiSiteba Padang, Sumatera Barat

2. Etty Rekawati : Departemen Keperawatan Komunitas Fakutas Keperawatan Universitas Indonesia, Depok 164242, Indonesia.

3. Dwi Nurviyandari: Departemen Keperawatan Komunitas Fakultas Keperawatan Universitas Indonesia,

Depok 16424, Indonesia

Email*: yusriana.yus@yahoo.com

\begin{abstract}
Abstrak
Penurunan fungsi dan kemampuan tubuh lansia membuat pemenuhan kebutuhan dasar menjadi tidak adekuat, sehingga menyebabkan penurunan kualitas hidup. Kelemahan fisik yang dialami lansia menyebabkan keterbatasan, maka persepsi terhadap kesehatan juga akan menurun. Tujuan penelitian ini adalah mengidentifikasi hubungan pemenuhan kebutuhan dasar dengan kualitas hidup lansia di Kelurahan Srengseng Sawah Kecamatan Jagakarsa Jakarta Selatan. Desain penelitian ini menggunakan pendekatan cross sectional study dengan jumlah sampel 111. Pengambilan sampel dilakukan dengn cara purposive sampling. Analisis bivariat dengan menggunakan uji spearman rank, sedangkan untuk analisis multivariat menggunakan uji regresi linear ganda terhadap konfounding yaitu karaktersitik lansia. Didapatkan hasil karakteristik umur (median=67,00), jenis kelamin perempuan $(75,7 \%)$ dan pendapatan rendah $(71,2 \%)$ merupakan konfounding dengan masing-masing nilai untuk umur $\mathrm{p}=0,00$, jenis kelamin $\mathrm{p}=0,057$, dan pendapatan $\mathrm{p}=0,130$. Pemenuhan kebutuhan dasar dengan kualitas hidup mempunyai hubungan yang signifikan. Disarankan agar perawat dalam meningkatkan kualitas hidup lansia yang mengalami kelamahan atau kemunduran secara fisik sehingga tidak mampu dalam pemenuhan kebutuhan dasar adalah dengan cara menurunkan dan mengatasi gejala yang dialami lansia serta meningkatkan persepsi positif terhadap lansia.
\end{abstract}

Kata Kunci: Pemenuhan Kebutuhan Dasar, Kualitas Hidup, Lansia.

Abstract

The decrease function and ability of the older people's body make the fulfillment of basic needs in adequate. It causes decrease in quality of life. When the older people's feels perceived physical weakness as limitation, so the perception of health will decrease too. This study aimed to identify the correlation fulfillment of bacic need with older people's quality of life in Srengseng Sawah South Jakarta. Analytic correlation was used as design of this research with cross sectional study approach. This study used 111 samples, where as purposive sampling is applied in sample collection. In multivariate, paired linear regression is used to know characteristics confounding. The result were age (median=67,00), sex is women 84 person $(75,7 \%)$ and buttom income 79 person $(71,2 \%)$ as confounding with $p$ value 0.00 for age, sex with $p$ value 0.057 and $p$ value for income 0.130. There is correlation with fulfillment of basic needs and quality of life in older people's. This study suggest to increase quality of life in weakness or physical decrease in older people's by over whelming the symptoms and positive improvement of older people's perception.

Key word: Fulfillment of basic needs, quality of life, older persons 


\section{PENDAHULUAN}

Berdasarkan data Kementerian Kesehatan RI (2014) didapatkan peningkatan proyeksi rerata usia harapan hidup pada lansia. Tahun 2010-2015 sebesar 1,1 dari 69,6 menjadi 70,7 tahun. Usia Harapan Hidup (UHH) penduduk Jakarta Selatan pada tahun 2013 adalah 73,96 tahun lebih tinggi jika dibandingkan tahun 2012 yaitu 73,87 tahun (BPS, 2010).

Jumlah lansia yang semakin meningkat berdampak pada peningkatan ketergantungan lansia karena kemunduran fisik, psikis, dan sosial lansia yang dapat digambarkan melalui empat tahap, yaitu kelemahan, keterbatasan fungsional, ketidakmampuan, dan keterhambatan yang akan dialami bersamaan dengan proses kemunduran akibat proses menua (Komnas Lanjut Usia, 2010).

Kelompok lansia dikatakan sebagai populasi rentan (vulnerable population) yang mempunyai resiko atau kerentanan mengalami gangguan kesehatan. Hal ini diperjelas dalam konsep konsekuensi fungsional, bahwa individu yang dapat mengkompensasi perubahan yang terjadi pada dirinya baik secara fisik maupun psikologis pengaruhnya terhadap dampak kehidupan lansia tersebut (Miller, 2012).

Pengaruh psikologis akan mempengaruhi kesehatan lansia yang berdampak dalam pememenuhan kebutuhan fisik dan kebutuhan psikis dalam pemenuhan kebutuhan hidup sehari-hari. Menurut Handerson (1978 dalam Aligood, 2011), bahwa kebutuhan dasar manusia terdiri dari bernafas normal, nutrisi, eliminasi, istirahat dan tidur, gerak dan keseimbangan tubuh, berpakaian, temperatur tubuh, personal hygiene, keamanan dan keselamatan, berkomunikasi dan berpendapat, beribadah, bekerja, rekreasi dan kesehatan tercukupi dan pemanfaatan pelayanan kesehatan.

Kebutuhan dasar manusia lebih utama untuk dilakukan Pemenuhan daripada kebutuhan lainnya karena dapat memberikan pengaruh terhadap kualitas hidup manusia. Kebutuhan dasar lansia yang terpenuhi dengan baik mewujudkan kualitas hidup lansia juga baik. World Health Organization (WHO, 2014) mendefinisikan kualitas hidup sebagai persepsi individu terhadap kehidupannya di masyarakat dalam konteks budaya dan sistem nilai yang ada terkait dengan tujuan, harapan, standar, dan perhatian.

Penelitian Anindo Majumdar (2013) pada 900 lansia di Perkotaan Puducherry India yang didapatkan kualitas hidup lansia dinegaranegara berkembang seperti India masih diabaikan, dan lansia yang mengalami kualitas hidup kurang baik itu adalah lansia yang tidak mempunyai pasangan hidup, kualitas pendidikan rendah, tidak menerima pensiun, adanya gangguan pada muskuloskletal dan mempunyai penyakit degenaratif atau kronis sehingga tidak bisa memenuhi kebutuhan dasar secara maksimal.

Studi pendahuluan di Kelurahan Srengseng Sawah dari 40 orang lansia diantaranya $20 \%$ lansia tinggal bersama pasangan, 7,5\% lansia tinggal sendiri tanpa pasangan, dan $72,5 \%$ lansia tinggal bersama keluarga seperti anak atau saudara. Dari data tersebut lansia yang tinggal bersama pasangan, kualitas hidupnya lebih bagus dibandingkan dengan lansia yang tinggal sendirian, dan lansia yang tinggal bersama keluarga seperti anak atau saudara jauh lebih bagus kualitas hidupnya dibandingkan dengan lansia yang tinggal sendirian maupun lansia yang tinggal berdua saja dengan pasangannya. Keterbatasan fisik dalam pemenuhan kebutuhan dasar seperti pemenuhan kebutuhan yang disebabkan karena ketidakmampuan fisik untuk melakukan semua afkitifitas secara maksimal sehingga tidak mampu memenuhi kebutuhan sehari-harinya. Penelitian ini melihat hubungan pemenuhan kebutuhan dasar dengan kualitas hidup lansia di Kelurahan Srengseng Sawah Kecamatan Jagakarsa Kota Jakarta Selatan.

\section{METODE PENELITIAN}

Desain penelitian ini adalah studi korelasi dengan jenis penelitian analitic correlation melalui pendekatan cross sectional study. 
Populasi adalah keseluruhan subjek penelitian yang diteliti (Sastroasmoro \& Ismael, 2011). Dalam penelitian ini populasinya adalah lansia yang berusia lebih 60 tahun dan berada di Wilayah Jakarta Selatan yang terdiri dari 10 Kecamatan yaitu 76.919 orang lansia (Profil DKI Jakarta, 2012). Jumlah sampel sebanyak 111 responden.

Kuesioner yang digunakan dalam penelitian ini adalah pengembangkan kuesioner pemenuhan kebutuhan dasar lansia berdasarkan teori Virginia Handerson sebanyak 27 item pertanyaan yang terdiri dari kebutuhan bernafas normal, nutrisi, eliminasi, istirahat dan tidur, gerak dan keseimbangan tubuh, berpakaian dan personal hygiene, mempertahankan temperatur tubuh, rasa aman dan nyaman, komunikasi dan berpendapat (hubungan sosial), beribadah (spiritual), berprestasi, rekreasi, dan kesehatan dan pemanfaatan pelayanan kesehatan. Sedangkan untuk pertanyaan kualitas hidup berdasarkan WHOQOL-BREF terdiri dari 26 item pertanyaan yang terdiri dari kualitas hidup secara fisik, psikologis, hubungan sosial dan lingungan.

Uji validitas instrumen menggunakan Pearson Product Moment, dari 27 item pernyataan dua diantaranya dilakukan modifikasi kalimat pernyataan sehingga menjadi valid. Uji reliabilitas digunakan uji Cronbach Alpha, diperoleh 0,9 sehingga instrumen memenuhi nilai realiabel yang ditetapkan yaitu $\geq 0,6$ (Hastono, 2012).

\section{HASIL PEMBAHASAN}

Usia responden dalam penelitian ini, yaitu 67,00 tahun (95\% CI : 66,34-68,63), dengan rentang usia termuda 60 tahun dan umur tertua 87 tahun.

Karakteristik responden lansia kelamin perempuan 84 orang $(75,7 \%)$, memiliki pendidikan rendah sebanyak 104 orang $(93,7 \%)$, dengan pendapatan lansia sebagian besar adalah rendah sebanyak 79 orang $(71,2 \%)$, memiliki asuransi kesehatan yaitu sebanyak 95 orang $(85,6 \%)$ memiliki penyakit kronis sebanyak 75 orang $(67,6 \%)$, dan tipe keluarga lansia sebanyak 59 orang $(53,2 \%)$ tinggal bersama keluarga besar (extended family).

Tabel 1 Gambaran karakteristik lansia di Kelurahan Srengseng Sawah Kecamatan Jagakarsa Jakarta Selatan Tahun $2016(\mathrm{n}=111)$

\begin{tabular}{lcc}
\hline \multicolumn{1}{c}{ Karakterisitik } & Frekuensi & Presentase \\
& & \\
\hline Jenis kelamin & & \\
$\quad$ Perempuan & 84 & 75,7 \\
$\quad$ Laki-laki & 27 & 24,3 \\
\hline Pendidikan & 104 & 93,7 \\
$\quad$ Rendah & 7 & 6,3 \\
$\quad$ Tinggi & & \\
\hline Pendapatan & 79 & 71,2 \\
$\quad$ Rendah & 32 & 28,8 \\
$\quad$ Tinggi & & \\
\hline Asuransi kesehatan & 16 & 14,4 \\
Tidak ada & 95 & 85,6 \\
$\quad$ Ada & & \\
\hline Penyakit & 36 & 32,4 \\
Akut (3-6 bulan) & 75 & 67,6 \\
$\quad$ Kronis (> 6 bulan) & & \\
\hline Tipe keluarga & 17 & 15,3 \\
Keluarga tinggal sendiri & 35 & 31,5 \\
Keluarga inti & 59 & 53,2 \\
$\quad$ Extended family & $\mathrm{n}=111$ & \\
\hline Total & & \\
\hline
\end{tabular}

Tabel 2 Gambaran Pemenuhan Kebutuhan Dasar dan Kualitas Hidup Responden di Kelurahan Srengseng Sawah Kecamatan Jagakarsa Jakarta Selatan Tahun $2016(\mathrm{n}=111)$

\begin{tabular}{|c|c|c|c|c|c|}
\hline Variabel & Median & $\begin{array}{l}\text { Min- } \\
\text { Maks }\end{array}$ & $\begin{array}{c}95 \% \\
\text { CI }\end{array}$ & korelasi & $\begin{array}{c}P \\
\text { value }\end{array}$ \\
\hline \multirow{3}{*}{$\begin{array}{l}\text { Pemenuhan } \\
\text { kebutuhan } \\
\text { dasar }\end{array}$} & 91,00 & 63- & $87,86-$ & & \\
\hline & & 143 & 92,23 & & \\
\hline & & & & 0,533 & 0,000 \\
\hline $\begin{array}{l}\text { Kualitas } \\
\text { Hidup } \\
\text { Lansia }\end{array}$ & 92,00 & $\begin{array}{l}66- \\
107\end{array}$ & $\begin{array}{c}89,04- \\
93,01\end{array}$ & & \\
\hline
\end{tabular}

Nilai tengah pemenuhan kebutuhan dasar responden dalam penelitian ini adalah 91,00 $(95 \%$ CI $=87,86-92,23)$ dengan rentang terendah 63 dan tertingi 143. Nilai tengah kualitas hidup responden dalam penelitian ini adalah 92,00 (95\% CI =89,04-93,01) dengan rentang 66-107, $\mathrm{p}$ value $=0,000$ yang menunjukkan bahwa korelasi antara skor pemenuhan kebutuhan dasar dengan kualitas 
hidup lansia bermakna. Nilai korelasi Spearman (r) sebesar 0,533 artinya pemenuhan kebutuhan dasar dapat memberikan pengaruh terhadap kualitas hidup lansia sebesar 53,3\%. Nilai korelasi tersebut juga menunjukkan korelasi positif dengan kekuatan korelasi kuat. terdapat hubungan anatar pemenuhan kebutuhan dasar dengan kualitas lansia.

\section{Pemodelan Akhir Multivariat}

\begin{tabular}{|c|c|c|c|c|c|c|c|}
\hline \multirow{3}{*}{ 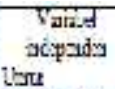 } & \multirow{3}{*}{$\begin{array}{c}\text { ? } \\
\text { squere }\end{array}$} & \multirow[t]{2}{*}{ Crilal. } & \multirow{2}{*}{$\begin{array}{l}\text { Peujadin } \\
\text { cosfiar }\end{array}$} & \multirow[t]{2}{*}{ Cuelitsica } & \multirow[t]{2}{*}{ pvidus } & \multicolumn{2}{|c|}{ Collbezi. Stabli. } \\
\hline & & & & & & Therenth & जII \\
\hline & & & $1.3^{2}$ & 0.78 & 0.20 & 6.816 & L.182 \\
\hline Jut bsurit & 0,44 & 10.589 & $230 \%$ & 1654 & $0,2 \%$ & $6870^{\circ}$ & $4,(\bar{S})$ \\
\hline Pexicuran & & & $378 \%$ & 2624 & 0.132 & 6958 & L.MI \\
\hline Ketrit hes liace & & & $i^{\prime}$ & जऊा & $\pi 0^{-1}$ & 10 & $T 2 N$ \\
\hline
\end{tabular}

Berdasarkan Dari perhitungan pemodelan terakhir ini perubahan nilai Coeffisiensi B pada masing-masing-masing variabel, setelah variabel asuransi kesehatan, penyakit, tipe keluarga dan pendidikan dikeluarkan secara bertahap ternyata ada dua variabel yang mengalami perubahan lebih dari $10 \%$ yaitu variabel jenis kelamin $(23,0 \%)$ dan pendapatan $(37,8 \%)$, dengan demikian variabel jenis kelamin dan pendapatan tidak dikeluarkan dan dipertahankan dalam pemodelan multivariat, menunjukkan faktor yang berkontribusi terhadap kualitas hidup lansia yaitu usia, jenis kelamin, pendapatan, dan kebutuhan dasar, dengan demikian proses pencarian yang masuk dalam model telah selesai dan langkah selanjutnya adalah uji asumsi. Pada tabel 5.8 juga terlihat kooefeisien determinasi ( $\mathrm{R}$ square) menunjukkan nilai 0,444 , artinya bahwa model regresi yang diperoleh dapat menjelaskan $44,4 \%$ variasi variabel dependen kualitas hidup lansia. Kemudian pada kotak ANOVA dapat dilihat hasil uji $F$ yang menunjukkan nilai $\mathrm{p}=0,000$, berarti pada alpa 5\% dapat dinyatakan bahwa model regresi cocok (fit) dengan data yang ada atau dapat diartikan kedua variabel tersebut secara signifkan dapat untuk memprediksi kualitas hidup lansia.

Berdasarkan hasil analisis tabel 1 dan 2 diperoleh nilai $\mathrm{p}=0,000$ yang menunjukkan bahwa korelasi antara skor pemenuhan kebutuhan dasar dengan kualitas hidup lansia bermakna. Nilai korelasi Spearman (r) sebesar
0,533 menunjukkan korelasi positif dengan kekuatan hubungan kuat. Hal ini menunjukkan korelasi linear positif sempurna, artinya setiap kenaikan satu variabel diikuti kenaikan variabel yang lain yaitu semakin terpenuhi kebutuhan dasar lansia maka semakin baik kualitas hidupnya.

Hal ini didukung oleh Darmojo (2006) menjelaskan bahwa lansia yang mengalami gangguan dalam pemenuhan Activity Daily Living (ADL) maka akan mengalami perubahan dalam kualitas hidupnya. Dalam studinya tersebut dinyatakan bahwa ada hubungan antara kemampuan dalam pemenuhan Activity Daily Living (ADL) dengan kualitas hidup lansia. Hasil uji statistik dengan $p=0,004$ dan hal ini dapat disimpulkan bahwa kedua variabel memiliki hubungan.

Berdasarkan data hasil penelitian diatas analisis peneliti yaitu dengan adanya kemampuan atau kemandirian dalam melakukan pemenuhan kebutuhan dasar ataupun pemenuhan Activity Daily Living (ADL), berarti lansia sudah meningkatkan kualitas hidupnya sendiri. Kemampuan atau kemandirian lansia juga harus didukung faktor lain seperti ada atau tidaknya penyakit kronis, fasilitas, dan dukungan dari keluarga atau pun teman sebaya.

Teori pendukung dalam pembahasan ini adalah teori penuaan yang terdiri dari teori biologis dan psikologis (Stanley\&Beare, 2007). Dalam teori biologis menjelaskan bahwa dalam proses fisik penuaan termasuk perubahan fungsi dan struktur, pengembangan, lamanya usia dan kematian. Perubahan-perubahan dalam tubuh termasuk perubahan molekuler dan seluler dalam sistem organ utama dan kemampuan tubuh untuk berfungsi secara adekuat dan melawan penyakit. Teori biologis ini dijelaskan tentang Wear and tear theory, menjelaskan bahwa tubuh dan selnya mengalami kerusakan karena sering digunakan dan disalahgunakan (overuse and abuse). Organ tubuh seperti hati, lambung, ginjal, kulit, dan yang lainnya, menurun karena toksin didalam makanan dan 
lingkungan, konsumsi kelebihan lemak, gula, kafein, alkohol, dan nikotin, karena sinar ultraviolet, dan karena stress fisik dan emosional. Teori ini memperlihatkan bahwa mengapa kegagalan atau kerusakan fungsi organ tubuh merupakan penyebab yang paling sering pada kematian, sel-sel yang mempunyai fungsi penting pada jaringan ini tidak mempunyai kemampuan regenerasi.

Organ tubuh yang sering digunakan atau disalahgunakan akan menimbulkan penyakit kronis yang berdampak pada masa lanjut usia. Sehingga lansia sering mengeluhkan gangguan pada organ tubuh tertentu. Hal ini berkaitan erat dengan teori pemenuhan kebutuhan dasar menurut Handerson (1978 dalam Alligod \& Tomey MA, 2011), lansia yang mengalami kemunduran fisik atau memiliki penyakit kronis biasanya akan mengeluhkan gangguan seperti bernafas normal, kebutuhan nutrisi, kebutuhan eliminasi, serta kebutuhan gerak dan keseimbangan tubuh. Adanya penyakit kronis pada lansia akan berdampak pada pemenuhan kebutuhan istirahat dan tidur. Sekitar $10 \%$ lansia mengalami gangguan pemenuhan kebutuhan tidur (Ebersole, 2005). Miller (2012) mengatakan gangguan pemenuhan kebutuhan tidur ini disebabkan oleh adanya rasa nyeri, ketidaknyamanan, mitos, kecemasan, depresi, efek obat, kondisi patologis, dan faktor lingkungan. Selain berdampak pada pemenuhan kebutuhan tidur, adanya gangguan kronis pada fisik juga dapat menyebabkan peningkatan ketergantungan lansia sehingga bisa berdampak pada gangguan pemenuhan kebutuhan berpakaian dan personal hygiene.

Kesadaran lansia akan pentingnya kesehatan misalkan dengan melakukan pemeriksaan secara berkala dapat mempengaruhi kualitas hidup lansia. Upaya kesehatan yang dilakukan oleh lansia dan didukung oleh kegiatan posbindu atau posyandu lansia dan melakukan kegiatan upaya pencegahan penyakit, ini menunjukkan bahwa pemenuhan kebutuhan akan kesehatan dan pemanfaatan fasilitas kesehatan lansia tercukupi dengan baik, begitu juga jika terjadi sebaliknya maka pemenuhan kebutuhan dasar lansia tidak terpenuhi yang akan memberikan dampak pada kualitas hidup lansia.

Kaitan teori biologi ini dengan variabel penelitian adalah bahwa penurunan fisiologis fisik pada lansia sesuai teori wear and tear akan menurunkan kemampuan lansia dalam melakukan aktivitas sehari-hari. Penurunan ini yang dapat menyebabkan pemenuhan kebutuhan dasar lansia tidak dapat terpenuhi dengan baik, sehingga berdampak pada kualitas hidup lansia menjadi tidak baik juga. Namun sebaliknya jika kebutuhan biologis dapat terpenuhi dengan baik maka kebutuhan pemenuhan kebutuhan dasar juga akan terpenuhi dengan baik pula dan memberikan dampak pada kualitas hidup yang baik pula.

Selain teori biologis dalam teori penuaan juga terdapat teori psikologis, yang merupakan bentuk teori yang memusatkan pada perubahan sikap dan perilaku yang menyertai peningkatan usia sebagai implikasi biologi pada kerusakan anatomis. Dalam teori ini perubahan sosiologis atau nonfisik dikombinasikan dengan perubahan psikologis (Stanley \& Beare, 2007). Teori psikologis ini menjelaskan bahwa untuk menuju penuaan yang sukses maka individu harus tetap beraktivitas. Aktivitas fisik erat kaitannya dengan lingkungan sekitar tempat tinggal. Kehilangan peran di masyarakat, hambatan kontak fisik, dan berkurangnya komitmen merupakan penyebab perubahan sosial (Ebersole \& Hess', 2014). Dalam hal ini yang merupakan bagian kebutuhan psikologis dalam kebutuhan dasar menurut Handerson (1978 dalam Alligod \& Tomey MA, 2011), yaitu kebutuhan keamanan dan keselamatan, kebutuhan komunikasi dan berpendapat, kebutuhan beribadah (spiritual), dan kebutuhan bekerja dan rekreasi.

Kaitan teori psikologis ini dengan variabel penelitian adalah dengan bertambahnya usia seseorang atau menjadi lansia biasanya akan menyebabkan perubahan dalam melakukan aktivitas dilingkungan sekitar atau interaksi sosial. Perubahan ini dapat disebabkan oleh 
faktor keterbatasan fisik atau tingkat ketergantungan lansia.

Kebutuhan biologis maupun psikologis juga dapat dipengaruhi oleh pemenuhan kebutuhan mempertahankan temperatur tubuh atau sirkulasi, dikarenakan kualitas fisik dan lingkungan suatu wilayah pemukiman perlu diketahui sebelum kita akan tinggal diwilayah tersebut, karena suatu wilayah yang dimiliki kualitas fisik dan lingkungan yang baik akan berpengaruh baik secara fisik maupun psikologis.

Nilai korelasi Spearman (r) sebesar 0,533 menunjukkan korelasi positif dengan kekuatan hubungan kuat. Penelitian Darmojo (2006) menjelaskan bahwa lansia yang mengalami gangguan dalam pemenuhan Activity Daily Living (ADL) maka akan mengalami perubahan dalam kualitas hidupnya.

\section{KESIMPULAN}

Terdapat hubungan pemenuhan kebutuhan dasar dengan kualitas hidup lansia di Kelurahan Srengseng Sawah Kecamatan Jagakarsa Jakarta Selatan, diperoleh nilai $\mathrm{p}<0,001$ yang menunjukkan bahwa korelasi antara skor pemenuhan kebutuhan dasar dengan kualitas hidup lansia bermakna, dengan korelasi positif dan kekuatan korelasi kuat. Faktor yang paling berkontribusi terhadap hubungan pemenuhan kebutuhan dasar dengan kualitas hidup lansia setelah dikontrol oleh variabel confounding yaitu jenis kelamin.

Hasil penelitian ini diharapkan dapat menjadi acuan dalam perencanaan dan pengembangan program kesehatan lansia, khususnya terkait pemenuhan kebutuhan dasar dengan kualitas hidup lansia dan menjadi salah satu program yang perlu dikembangkan oleh Dinas Kesehatan sebagai upaya promotif dan preventif dalam menggerakkan kader dan mengembangkan program posbindu PTM dari masing-masing RW. Hasil penelitian ini dapat menjadi bahan data dasar penelitian selanjutnya dalam upaya mencari fenomenafenomena yang berhubungan dengan pemenuhan kebutuhan dasar lansia misalnya pengaruh pendidikan kesehatan,hubungan dukungan keluarga dengan pemenuhan kebutuhan dasar dan hubungan dukungan kelaurga dengan kualitas hidup lansia.

\section{UCAPAN TERIMAKASIH}

Ucapan terima kasih kepada Dekan Fakultas Ilmu Keperawatan Universitas Indonesia dan STIKES MERCUBAKTIJAYA Padang yang telah memberikan dukungan penuh dalam penelitian ini. Seluruh pihak yang membantu kelancaran penelitian ini terutama pada pihak Kelurahan Srengseng Sawah Kecamatan Jagakarsa yang telah memberikan ijin penelitin dan Kelurahan Pondok Cina sebagai tempat uji validitas dan reliabilitas.

\section{REFERENSI}

Agnes, D. A. (2013). Hubungan Dukungan Keluarga dengan Kualitas Hidup Lansia Hipertensi di Wilayah Kerja Puskesmas Palangkaraya. Tesis tidak dipublikasikan.

Allender, J.A., Rector, C.,\& Warner, K.D. (2014).Community \& Public Health Nursing Promoting The Public's Health(8th ed.). Philadelphia: Lippincott Williams \& Wilkins

Badan Pusat Statistik (BPS). (2010). Proyeksi Penduduk Indonesia Indonesia Population Projection 2010-2035. Jakarta: Badan Pusat Statistik

Dickerson, S. Elated S., Kennedy, M., Wu, Y. W. B., Underhill, M., \& Othman, A. (2010). Factors related to quality of life pattern changes in recipients of implantabledefibrillators. Heart \& Lung. Advance online publication. doi.10.1016/j.hrtlng.2009.10.22.

Ebersole, P., Hess, P., \& Touhy, T. (2014). Gerontological Nursing \& Helathy Aging. (2nd ed). 
Friedman, M.M., Bowden, V.R.,\& Jones, E.G. (2010). Family nursing: Research, theory, and practice $\left(5^{\text {th }} \mathrm{ed}\right.$.).Connecticut: Appleton \& Lange.

Ganesh Kumar, Anindo Majumdar, dan Paviitrha G. (2014), Quality of Life (QOL) and Its Associated Factors Using WHOQOL-BREF Among Elderly in Urban Puducherry, India Pavithra G.doi: 10.7860/JCDR/2014/6996.3917

Miftahurrohmah. L,. (2015). Hubungan antara status gizi dengan kualitas hidup lansia diposyandu lansia Bantul. http://jurnalscholar/detail.php?dataid=1057 .diunduh 21 Maret 2016.

Miller, C. A. (2012). Nursing for wellness in older adult: theory and practice (6th ed.). Philadelphia: Lippincott Williams \& Wilkins.

Polit, D.F \& Beck, C.T. (2012). Nursing Research: Generating and Assessing Evidence of Nursing Practice. ( $9^{\text {th }}$ ed.). Philadelphia: Lippincolt Williams\& Wilkins.

Risdianto. 2009. Hubungan Dukungan Sosial dengan Kualitas Hidup Lanjut Usia di Desa Kembang Cepogo Boyolali. Skripsi tidak dipublikasikan. Surakarta: UMS

Sarath Rathnayake and Sidiah Siop (2015), Quality of Life and Its Determinants among Older People Living in the Rural Community in Sri Lanka. Indian Journal of Gerontology, Vol. 29, No. 2, pp. 131-153.

Sastroasmoro, S. \& Ismael, S. (2011). Dasardasar metodologi penelitian klinis. Jakarta: Sagung Seto
Sudinkes Jakarta Selatan, (2015). Laporan pembinaan kesehatan lanjut usia triwulan I dan II tahun. Jakarta Selatan: Sudinkes Jakarta Selatan.

Tavares, D.M.S., Dias, F.A., Santos, N.M.F., Hass, V. D., \& Miranzi, S. C. S. (2012). Factors associated with the quality of life of elderly mrn. Rev Esc Enferm USP. 47, 673-680. doi:10.1590/S0080623420130000300022 .

Ulfa, L. K. (2014). Hubungan Tingkat Stress dan Peningkatan Tekanan Darah Terhadap Kualitas Tidur Penderita Hipertensi Lansia. http://jurnalscholar/detail.php?=ypdid:541 0.diunduh 27 Maret 2016.

Universitas Indonesia. (2008). Pedoman teknis penulisan tugas akhir mahasiswa Universitas Indonesia.

Vini Cahyani, (2014). Konsumsi Cairan dan Status Hidrasi pada Lansia di Panti Sosial Tresna Werdha Mulia Dharma Kabupaten Kubu Raya. Tesis tidak dipublikasikan

WHO. (2004), WHO Quality of Life BREF. Genevan: Word Health Organization. 